\title{
Friends or Foes? Migrants and Sub-state Nationalists in Europe
}

Sanjay Jeram, Arno van der Zwet and Verena Wisthaler

Brock University, St. Catharines, Canada

European Policies Research Centre, University of Strathclyde, Glasgow, Scotland

Institute for Minority Rights, EURAC, Bolzano, Italy/Politics and International Relations, University of Leicester, United Kingdom

sjeram@brocku.ca

arno.van-der-zwet@strath.ac.uk

verena.wisthaler@eurac.edu 


\section{Friends or Foes? Migrants and Sub-state Nationalists in Europe}

How do sub-state nationalists respond to the growing presence of cultural diversity in their 'homelands' resulting from migration? Sub-state nationalists in Europe, in 'nations without states' such as Catalonia and Scotland, have been challenging the traditional nation-state model for many decades. While the arguments in favour of autonomy or independence levelled by these movements have become more complex, sub-state nationalist movements remain grounded by their perceived national community that is distinct from the majority nation. Migration to the 'homeland' of a sub-state nation, then, presents a conundrum for sub-state elites that we label the 'legitimation paradox': too much internal diversity may undermine the claim to cultural distinctiveness. We engage with three common intervening variables thought to influence how sub-state nationalists confront the 'legitimation paradox': civic/ethnic nationalism, degree of political autonomy and party competitiom. Our overarching argument is that none of these factors have a unidirectional or determinate affect on the sub-state nationalism-immigration nexus, which is why the nuanced case studies that comprise this Special Issue are worthwhile endeavours.

Keywords: multiculturalism, Europe, nationalism, regional parties, immigration

\section{Introduction}

Liberal democratic states in the West, such as Spain, Canada, the United Kingdom, Italy, and Belgium, are not only diverse due to the arrival of new immigrants, but also on account of sub-state nationalist movements that seek more autonomy, or even independence, to protect their cultural distinctiveness (Lecours 2012). The degree to which states recognize and accommodate their sub-state nations varies, but the trend towards regional autonomy and multinational federalism has been strong over the past few decades (Kymlicka 2007, 69). Accordingly, stateless nationalist and regionalist 
parties (SNRPs), which focus on protecting the identity, culture, and interests of a regional or national population, have been empowered and are now important actors in regional parliaments and party systems (Hepburn 2009). Because immigration has extended to regions with sub-state nationalist movements, such as Catalonia, South Tyrol, Scotland, Quebec, Flanders, Friesland, and the Basque Country, the central task of SNRPs to maintain group distinctiveness and promote sub-state interests vis-à-vis the national majority and central state has become much more complicated. This is why the 'politics of immigrant multiculturalism meet the politics of minority nationalism directly': by promoting internal diversity, SNRPs may undermine the basis for their claims of national distinctiveness within the state (Banting and Soroka 2012, 158). On the other hand, however, including newcomers in the sub-state national community may strengthen the hand of SNRPs by boosting the territory's demographic weight and enhancing its legitimacy as a liberal democratic actor (Barker 2010).

Immigrant-generated diversity has also presented some SNRPs with an opportunity to underscore their liberal credentials. Broad commitments to multiculturalism and diversity by SNRPs counteract the pejorative connotation of labels, such as separatism and minority nationalism, frequently evoked by states to dismiss SNRP agendas as radical or extremist (Tamir 1993). Moreover, by accommodating and promoting diversity, SNRPs can distinguish themselves from state-wide parties, especially since European centrist parties have, in recent years, supported restrictive immigration and integration legislation in response to 'hardening' public opinion and the vicissitudes of electoral competition (Akkerman 2012; Money 1999). 
SNRPs may also respond to immigrants differently because of their origins. Immigrants from the global South have, somewhat unexpectedly, been welcomed by some SNRPs as part of their broader fight against exclusion, poverty and inequality, or in the name of solidarity with people who have (also) been repressed by a cultural majority in their origin country (Jeram and Adam 2014). Internal migrants to sub-state nations can elicit various reactions by SNRPs. For example, migrants from central Spain in the midtwentieth century were met with fierce resistance in the Basque Country and welcomed as 'new Catalans' in Catalonia (Conversi 1997). SNRPs in Quebec have, at times, expressed a preference for foreign migrants because newcomers from other parts of Canada are thought to be more resistant to acquiring French and encouraging their offspring to become 'native' speakers of the language. In the midst of current debates about a return to 'old style nationalism' in Europe, however, SNRPs may adopt a more favourable stance to internal migrants because of their greater perceived capacity for cultural assimilation (Joppke 2008).

Collectively, the case studies developed in this Special Issue highlight that the political responses and attitudes of SNRPs toward immigrant-generated diversity are complex and multifaceted. While some SNRPs embrace multiculturalism and extensive citizenship rights for newcomers, others are pushing for limits to migration and stricter citizenship obligations in order to shape the cultural 'core' of the nation. In most cases, both inclusive and exclusive understandings of the nation can be found in the policy and discursive responses of SNRPs to ethnic diversity (Laxer, Carson, and Korteweg 2014).

As a prelude to the analyses that will follow in the individual papers, this introductory article outlines the key concepts, issues, and empirical arguments that have 
been discussed in the scholarly literature thus far. We focus on three main conceptual and empirical debates that further our understanding of how SNRPs confront immigrants and diversity: whether SNRPs adopt civic or ethnic nation-building strategies at the sub-state level; the regionalization of integration and citizenship competencies on account of SNRP battles with the central state; and the emergence of regional party systems that revolve around both ideological and 'nationalist' axes. We then turn to a short summary of the individual papers prior to some concluding remarks.

\section{Are SNRPs Inherently Ethnic Nationalists?}

The popular ethnic/civic nationalism distinction projects two diametrically opposed versions of the nation. The ethnic variant uses 'objective' criteria, such as race or descent, which cannot be changed after birth as its basis for inclusion. On the other hand, the civic nation is inclusive, defined as a community of laws that anyone can join by respecting its governing rules, which generally include the protection of individual rights. The distinction is rooted in Kohn's (1945) differentiation between developmental paths in the 'liberal civic West' and 'illiberal ethnic East'; strictly speaking, Kohn argues that ethnic nationalism is a consequence of a 'backwards' economy, corrupt state, and the absence of liberal values. Its contemporary usage, though, is less explicit about the pathway to each type of nation; the distinction mostly boils down to the exclusivity of a nation's membership criteria (Koning 2011).

Early theorizing about the future of sub-state nations characterized them as 'small and backward' peoples who had everything to gain from merging into the 'greater nations' (Hobsbawm 1990, 34). Because the great nation-states (e.g., France, Britain, 
etc.) fit with the paradigm of modern development, dividing them was considered illegitimate, which facilitated the castigation of sub-state nations as anti-modern and parochial. Applying this logic, some scholars portrayed sub-state nations as inherently defined by ethnicity, bound to challenge and disrupt the civic nationalisms of their respective states (Franck 1997; Hollinger 1995; Ignatieff 1993). On this view, sub-state nationalist movements, and their political manifestations, SNRPs, were seen to be hostile to diversity and immigration.

The supposed inherent tension between sub-state nations and immigrants is certainly not a universal empirical fact. A primary SNRP in the Basque Country, Partido Nacionalista Vasca (PNV), defined the Basque nation according to 'blood and soil' principles in response to waves of Spanish migrants that arrived in the Bilbao area during the late nineteenth century (Douglass 2002; Zabalo 2008). By the middle of the twentieth century, however, PNV had lifted its lineage-based membership criteria and began to include Spanish migrants who supported the fight for democracy and autonomy in the ‘imagined' Basque nation (Conversi 1997, 202). A similar shift can be observed in Quebec. Early twentieth century elites in the province shaped a national identity based on French ancestry and rejected immigrants of Anglo-Saxon, Germanic, and Slavic stock because of the threat they posed to the French language and traditions of les Canadiens (Cook 1975). Following a period of rapid modernization in the 1960s, the FrenchCanadian nation was recast by Parti Québécois (PQ) as a territorial nation aligning with the borders of Quebec, inclusive of all ethnicities committed to Québécois values, but most importantly, speaking French in public life (Barker 2010; Juteau 2003). 
To complicate matters, any attempt to categorize SNRPs as definitively civic or ethnic according to their responses to diversity inevitably runs into problems. Critiques of the civic/ethnic distinction suggest that it is impossible for any nation to have a pure form of civic or ethnic nationalism (Nieguth 1999; Yack 1999). At a basic level, membership in the civic nation cannot be strictly voluntary because the majority of its members do not make an explicit choice to belong and others may not be able to meet 'voluntary' obligations. Sub-state nationalist movements in Quebec, Catalonia, and Flanders are often referred to as linguistic nationalisms because of the defining role language plays in demarcating the sub-state from the state nation. Language has always presented somewhat of a conundrum for the civic/ethnic distinction; it is frequently described as a trait one is born with, as suggested by the term 'mother tongue'. Certainly, immigrants can acquire language, but such a process cannot replicate the process of being socialized and reared through a given language in its 'natural' context. Even near native fluency does not permit unfettered access to the cultural milieu that binds a nation together; language is 'deeply embedded into the core of our identities' (Urla 2012, 67).

The application of, and intentions behind, language rules and norms promulgated by SNRPs can vary greatly. Following the controversial enactment of restrictions to immigrants' access to certain social benefits in Spain, Convergència i Unió (CiU), the popular nationalist coalition, made use of its position as the dominant party in the Generalitat to define a Catalan citizenship that bestowed full access to benefits for everyone living in Catalonia (Hepburn 2011, 517). The CiU's 2001 immigration plan made mention of the importance of the Catalan language to national cohesion, but did not suggest a link between access to social benefits in Catalonia and language knowledge in 
an implicit or explicit manner. The party toughened its position later on, instigating a campaign to 'force' immigrants to speak Catalan in public spaces and promising a integration contract in 2006 that would link knowledge of Catalan to speedier access to non-essential social services (Jeram 2014). In a similar vein, SNRPs in Flanders are in favour of Dutch language courses for immigrants, with the political majority arguing that passing high-level Dutch language tests should be mandatory for all citizenship privileges (Jacobs 2004; Loobuyck and Jacobs 2009). While supporters contend that language obligations are intended to foster conditions supporting inclusion, the potential for exclusion is obvious and depends on expectations and how programs are administered (Goodman 2010).

Interestingly, SNRPs with linguistic imperatives have not necessarily followed the state-level trend of prioritizing the dominant language in response to migration. A main objective of the Frisian National Party in the Netherlands is to boost the prevalence of the Frisian language in Frisian province. At the same time, the party actively supports the acquisition of 'home' languages by immigrant-origin pupils (van der Zwet 2012).

Aside from language matters in self-proclaimed civic sub-state nations, SNRP gestures and policies illustrate that exclusionary conceptions of the nation continue to coexist and conflict with territorially based identities. The Scottish National Party (SNP), for example, has been quite successful at crafting an image of 'Scottishness' that is cosmopolitan and open to diversity. The SNP has stated that it desires to develop a more efficient process for admitting migrants to Scotland, and wants to reduce the burdens of cultural adaptation; instead, the party encourages newcomers to 'retain a strong affinity to the country they came from' (Hepburn 2011, 513). The United Kingdom's rejection of 
multiculturalism and tightening of immigrant admissions has been used as fodder for the SNP's independence push; the party established pro-independence immigrant-led organizations such as 'Asian Scots for Independence' and 'New Scots for Independence'. SNP leader Alex Salmond has proudly claimed 'our Asian community amongst the most patriotic Scots in the country...with a clear majority supporting the SNP and independence' (Mycock 2012, 57).

The SNP may officially embrace a sense of identity that is "neither xenophobic nor exclusive', but evidence suggests that it may become increasingly difficult to maintain an 'impeccably civic' Scottish nationalism because for some Scots 'ethnic claims retain more purchase than civic claims' (Reicher, Hopkins, and Harrison 2009, 35). Mycock (2012) poses that one of the reasons segments of Scottish society, even those who vote for the SNP, have trouble considering new immigrants to be 'true Scots' is that the party has not eradicated images of its ethno-cultural past from its modern narrative. Alongside its pro-diversity position, the SNP has campaigned for closer ties to diaspora Scots in wealthy countries with the intention of luring some to 'come home'. The inaugural 'Homecoming Scotland' in 2009 was a series of events launched by the SNP targeted at 'blood' and 'ancestral' Scots, thus emphasizing that the party's vision of the nation is not purely territorial and civic; Scottish nationality is also attributed based on ethnic characteristics. Not surprisingly, the campaigns raised the ire of Scotland's ethnic minority communities, especially those supportive of the SNP and Scottish independence.

Diversity and immigration positions that straddle the civic/ethnic distinction are also evident in Flanders. Aside from the radical right-wing Vlaams Belang (VB), Flemish 
SNRPs, until recently, unanimously supported multicultural integration policies. Starting in the early 1980s, the Flemish Christian Democratic Party (CD\&V) and its governing partners executed policies, such as financing ethnic minority organizations, cultural diversity 'mainstreaming', and the creation of the 'Minorities Forum', to facilitate collaboration between ethno-cultural groups and the Flemish Government (Adam 2013). The multiculturalist aspects of the Flemish integration policy were expanded in the late 1990s even though the anti-immigrant VB had gained popularity. A representative of the mainstream nationalist party VolksUnie expressed the party's support for the continued emphasis on multiculturalism: 'not all nationalism is extremist or xenophobic'. This statement was made during debate in the Flemish Parliament and clearly directed at VB in order to demarcate that the majority of Flemish nationalists were both pro-immigration and pro-multiculturalism (Adam 2013).

Upon taking control of the Flemish executive, the Flemish liberals (VLD) successfully introduced a compulsory integration programme (inburgering) in 2003, which includes Dutch-language and social integration courses, with cross-partisan support. Inburgering has notable assimilationist intentions in that it obliges immigrants to learn 'common Flemish social norms and values' (Adam 2013, 557). At the same time, multicultural policy instruments, such as financing immigrant associations, were reinforced and a new policy to allow students to be 'legitimately' absent on religious holidays was implemented (Jacobs 2004).

The uneasy balancing act between civic and ethnic nationalism by SNRPs is indicative of the difficult 'legitimation paradox' they face: too much diversity may undermine the nation building process and lead to 'existential suicide' whereby a 
centralized individual rights framework empties the nation of its distinctive identity vis-àvis the state. Without formal control over admissions policy, a shift toward exclusionary and boundary-building policies by SNRPs may be a solution to avoid a decrease in the political and demographic weight of the sub-state nation within the larger state. The contrary liberal strategy of inclusion through multiculturalism at the sub-state level may be exploited by the central state as justification for state-wide multiculturalism under the umbrella of one loosely defined national identity based on the majority culture (Kymlicka 2011). Arguably, such developments will result in even more ambiguity as SNRPs try to avoid being labelled ethnic nationalists whilst preserving the mentality of 'la survivance', which makes sub-state nationalism a politically viable project.

\section{SNRPs and Decentralization: Immigration and Citizenship Below the State?}

The citizenship and immigration literature has drawn attention to the transfer of relevant competencies above the state. Europeanization and globalization have, arguably, weakened the state's capacity to confer or deny various citizenship rights to immigrants (Soysal 1994). At the same time, states have been decentralizing, thus empowering regions to govern in areas relevant to citizenship and integration, such as health, education, housing, culture, and labour market policy. As a result, SNRPs often control or influence integration-related policies through their presence in regional parliaments and executives (Hepburn 2011; Keating 2008). In some cases, the decentralization of integration and citizenship-related policies may be a result of state 'overload' or the pursuit of good governance; in other words, sub-state territories are presumed to be more efficient and effective at managing the integration process. In multinational states, 
regional governments and political parties may demand more competencies or stretch existing powers to ensure that migrants integrate into the cultural milieu of the sub-state nation. This is not an uncontested trend, though, as reception and citizenship policies can have significant effects on the demographic, linguistic, and cultural makeup of the immigrant population, which promotes participation by the central state and state-wide parties in policy-making as a means of nation-building and preventing separatism (Norman 2006).

While some SNRPs claim that citizenship policy should be decentralized to the sub-state region, along with other powers that would blur traditional lines of sovereignty, formal citizenship that is 'not just rhetorical and metaphorical' is still granted exclusively by the state (Joppke 2010,3). Yet, citizenship has evolved in the context of international migration so that holding a passport is no longer the only aspect of citizenship entangled with immigration. Even before the path to citizenship can begin, formal or otherwise, potential immigrants must be selected and formally admitted to the receiving state.

Entry is a core state function that is rarely, if ever, decentralized, but participation in or ownership of, the selection process by sub-state regions has become a legitimate aspiration. Because language is generally a core marker of sub-state national identities, SNRPs have an interest in controlling immigrant selection to buttress the demographic weight of the 'minority' language. Relatedly, SNRPs may prefer immigrants from sources that are likely to understand the culture of 'la survivance', which develops over the course of many years of struggle to maintain and revive non-state national cultures and support sub-state nationalist mobilizations (Kymlicka 2001, 67). SNRPs also sometimes have a different economic vision for their region, which can drive a preference 
for immigrants with particular skill sets and educational credentials. Finally, because substate nationalist movements cluster in underdeveloped or 'peripheral' territories (Hechter 1975), demographic challenges (e.g. outward migration, ageing population) to which immigration is a potential solution are often more acute. The distinctive characteristics of the sub-state region that supposedly necessitate control over immigrant selection may be genuine, but are also likely accentuated by SNRPs in order to bolster support for selfdetermination.

Another aspect related to citizenship, rights, is important because formal status creates an internal stratification of rights. For example, formal citizenship may create a distinction between nationals and non-nationals in terms of political rights (e.g. voting), but non-nationals may have available to them the same social rights (e.g. education, healthcare) as nationals. The calibration of citizen and non-citizen (immigrant) rights is variable cross-nationally and over time, not to mention that the vertical structure of the state affects both the official rights entitlements immigrants have and how such rights are administered. According to Greer and Mätzke (2009, 12), 'devolution reforms change citizenship...they change the governments that make citizenship rights real'. If a sub-state government has legislative and administrative control over education policy, but the central state restricts public school enrolment to formal citizens, an opportunity arises for contestation over the granting of citizenship rights, one which SNRPs and regional governments can, and do, win.

The identity aspect of citizenship relates to the beliefs and subjective attachment that the central or sub-state government seeks to impute on people. From the perspective of potential citizens, the identity component of citizenship refers to the sense of identity 
and belonging immigrants feel, 'and his or her allegiance to a given political community' (Hepburn 2011, 509). States vary to the extent that they associate formal citizenship with a cultural community by setting demanding requirements for knowledge of the national language and history, as well as for the adoption of particular values.

The connection between identity and citizenship has been strengthened in many European states that perceive a crisis of cohesion due to immigrant-generated diversity (Entzinger 2006; Mouritsen and Olsen 2013). The cultivation of attachment to the state identity is not limited to only formal citizens; governments are promoting common identities at earlier stages of the integration process (Goodman 2010). SNRPs and substate governments, especially those with strong nationalist aspirations, counter the statelevel 'citizenship agenda' by attempting to foster belonging to the sub-state national community among immigrants, either through force and sanction or with persuasion and argument. The 'sanction and force' model is exemplified by the CiU's recent proposals to link immigrants' access to social benefits to their knowledge of the Catalan language, whereas non-obligatory language-learning opportunities for immigrants and funded intercultural events personify the 'persuasion and argument' model (Triadafilopoulos 2011). It has been suggested that forceful attempts to build identification may turn potential friends into enemies, but some SNRPs in places like Quebec, Catalonia, and Flanders have scoffed at 'soft' approaches, arguing that they produce societal fragmentation and xenophobia among the native population.

Having established that SNRPs can affect integration and citizenship through regional governments leaves open an empirical question: does greater political autonomy condition the response of the SNRPs to immigrant-generated diversity? Kymlicka (2001) 
established a testable hypothesis through his interpretation of the Quebec case. There has been a dramatic change in how Québécois nationalists, including the PQ, perceive immigration and the nature of Québécois identity since the 1960s; national identity went from being ethnically exclusive to forward-looking and open to diversity (Blad and Couton 2009; Juteau 2003). Kymlicka attributes this shift to a successive number of changes to the structure of the state that gave Quebec shared competence over immigrant admissions and exclusive jurisdiction over settlement services. For Kymlicka $(2001,75)$, SNRPs will become increasingly 'post-ethnic' as the sub-state region gains control over the volume of immigrants and terms of integration. Control over volume is important to prevent the sub-state region from receiving more immigrants than it can absorb and integration powers allow SNRPs to incentivize immigrants to integrate into the subnational culture. The natural tendency of immigrants is to integrate into the majority society if given the choice, which leaves SNRPs in a tough spot since their omnipresent concern is the long-term survival of the sub-state national language and identity.

While helpful as a starting point, the empirical reality is generally much more complex; in the words of Barker $(2010,15)$, 'Kymlicka's schema is teleological to the extent that it envisions a progressive move towards post-ethnic multiculturalism'. His position overlooks the fact that a persistent tension exists between embracing diversity and apprehension of it regardless of the political status of the sub-state nation. In Quebec, PQ positioned itself as a champion of inclusiveness following the 1995 referendum, changing its image by emphasizing civic conceptions of the nation and supporting the notion of reasonable accommodation in the province (Nieguth and Lacassagne 2009, 7 8). Even though Quebec's control over immigrant selection and settlement is exclusive, 
the party somewhat reversed its stance in 2013 by supporting the controversial Charter of Values that would ban public servants from wearing religious symbols at work, a rule most agree targets Muslim disproportionately. The Basque Government, on the other hand, has no control over selection and shares competence over integration on account of Spain's 'efficiency model' whereby the state permits the Autonomous Communities to govern certain policy areas that could, according to the Spanish Constitution, belong to the state (Zapata-Barrero 2012). Nevertheless, PNV and its coalition partners have remained committed to their multiculturalist human rights agenda, challenging the statewide parties on their policies that have curtailed the social rights of immigrants.

Zapata-Barrero and Barker (2014) have recently outlined a more complex theory that ties the structure of the state to immigration and citizenship politics at the regional level. In their schema, immigration and citizenship policy is equally relevant to the statelevel parties and SNRPs because of their nation building implications, which means that more or less decentralization does not have a uniform affect on parties at the sub-state level. Reception and integration is the policy area most amenable to multilevel governance because the central state may recognize the 'efficiency' benefits that accrue from settlement programmes tailored to local conditions. Consequently, a cooperative scenario likely emerges in which the state attempts to steer policy while allowing much latitude to the regions. When regions have strong sub-state nationalist movements, however, cooperation is difficult because SNRPs push in favour of asymmetric decentralization. The position of SNRPs, then, is shaped by 'how much the politics of immigration intersects with the politics of multinationality in the state' rather than the specific structure of the state (Zapata-Barrero and Barker 2014, 55). Focusing on regions 
without nationalist movements, Schmidtke and Zaslove (2013) argue that greater subnational governance over immigrant integration leads to a depoliticization of this issue at the regional level and a greater focus on pragmatism. This tells us that there is still much work to be done to make sense of the interaction between identity and pragmatic concerns as they relate to immigration and integration in decentralizing multinational states.

\section{Party Politics and Immigration at the Regional Level: Are SNRPs 'Normal' Parties?}

Another strand of the immigration literature has focused on the influence political parties have on related policies. In canonical work by Brubaker (1992) and Soysal (1994), parties hardly factored in, as 'national traditions' and the development of international human rights norms were supposedly the driving forces behind citizenship and integration regimes. The lack of attention to parties in the early migration literature is partly explained by the persuasiveness of the 'hidden consensus' argument, according to which 'mainstream parties diffuse migration as an issue by managing policy out of the public's eye' (Triadafilopoulos and Zaslove 2006, 171). This started to change with the emergence of radical right-wing parties in Europe; scholars have taken note of how the presence of these parties affects debates and policy surrounding immigration and diversity (Bale et al. 2010). Research on the dynamics of political parties in immigration matters is still thin, but recent work suggests that the same 'rules' do not apply in regional party systems. This is especially true in regions with SNRPs that are, in essence, products of regional politics rather than affiliates of a centralist state-wide party (Hepburn 2009). 
A primary reason why SNRPs may not behave according to their ideological profile in the immigration ambit is the pre-eminence of the 'territorial' or 'nationalist' cleavage in regional party systems (Hepburn 2010). SNRPs, in particular, take account of how immigration might be framed in a manner that links the issue with the broader struggle for the defence of the nation or constitutional change. In Scotland, political debate on immigration-related issues take place on the 'left' even though it is a highly politicized matter in United Kingdom party politics. Even though they critique SNP proposals on immigration for English audiences (Johnson 2013), state-wide parties recognize it would be difficult to gain traction with Scottish voters by espousing 'tough' immigration and integration ideals because the SNP has effectively linked openness to diversity with the Scottish identity (Hepburn 2010). This intermingling of Scottish nationalism and pro-diversity discourses has crystallised despite the fact that attitudes towards immigrants between Scotland and most parts of England do not differ as much as usually suggested (Bromley, Curtice, and Given 2007). Perhaps anti-immigrant discourses have less traction in Scotland because immigration is a relatively new phenomenon there. A similar dynamic is evolving in the Basque Country; the rightleaning Partido Popular (PP), which capitalizes on xenophobia in state-wide elections, has remained somewhat muted with regards to immigrants' social rights in the Basque Country because the SNRPs have shaped a leftist frame for immigration debates. An ideologically centre-right party, PNV has also resisted populist anti-immigrant discourse on account of its legacy of racist nationalism, which drives its desire to bolster its liberal democratic credentials by emphasizing its resolutely civic understanding of the nation (Jeram 2013; Keating 2004, 367). The opposite has occurred in Bavaria where the 
Christian Social Union has politicized the supposedly 'soft' immigration policies of the German state and made liberal positions less tenable (Hepburn 2008). Certainly, the addition of the 'nationalist-centralist' axis to the party systems of devolved regions complicates the matter of how SNRPs respond to immigration.

The territorial aspect of party competition does not solely determine SNRP positions on immigration; matters that are more pragmatic in nature do factor into the analysis (Hepburn 2014). Most SNRPs are office-seeking parties, and so no longer can be considered niche parties; they have well-articulated socioeconomic programmes and have effectively moved from 'protest to power' by forming governments at the regional level and implementing legislation on various issues (Elias and Tronconi 2011). Consequently, SNRPs are prone to change their position on immigration issues on account of factors such as the state of the regional economy, regional party polarization, demographic shifts, and the structure of the electoral system (Hepburn 2014). Both identity and electoral concerns result in diverse immigration portfolios among SNRPs that are constantly in flux and much harder to predict than previously thought.

\section{Summary of Articles}

The papers in this Special Issue utilize a mix of analytical techniques with a focus on qualitative methods such as content and discourse analysis. The authors cull various data sources, such as elite interviews, party manifestos and party member surveys, and thus, in our opinion, contribute immensely to the emerging literature on immigrant-generated diversity and sub-state nationalism. Collectively, the papers focus on the challenges and opportunities that 'new' diversity is bringing to regions embroiled in 'old' long-standing 
nationalist conflicts. Even this relatively small research area has generated topics that cannot be covered here such as public opinion about immigration in sub-state nations (Escandell and Ceobanu 2010; Turgeon and Bilodeau 2014) and the normative obligations sub-state nationalists confront with respect to immigration (Carens 1995; Kymlicka 2001). Our focus on the political, policy, and attitudinal characteristics of SNRPs is justified: SNRPs are powerful actors in sub-state regions that are becoming ever more competent in areas related to immigrant integration.

Before briefly summarizing the main arguments of the authors, we point out our specific intention to complement a recent edited volume by Zapata-Barrero and Hepburn (2014) by covering regions (i.e. Friesland, Wales, Basque Country and South Tyrol) and SNRPs not covered in their book. By no means, however, is the contribution solely an empirical one, as a wide range of diagnoses and findings are generated by the exchange of ideas and interpretations between the authors.

Starting from the assumption that SNRPs in liberal democracies have generally shown an affinity for multiculturalism in official statements and proclamations, Arno van der Zwet delves into whether 'ordinary' members of SNRPs actually support prodiversity immigration policies. Examining two parties, SNP and the Frisian National Party (FNP), which are left-of-centre and self-proclaimed exemplars of civic SNRPs, he scrutinizes original and secondary data to determine if party members provide consistent opinions about immigration and diversity, and examines if varying opinions are derived from individual conceptions of national identity. He finds that party members who define the nation according to ethnic criteria report less favourable attitudes towards immigration and diversity. The findings raise important questions concerning the 
growing gap between the inclusive proclamations of party elites and the more conservative views of 'ordinary' members. Unique among the articles in this edition, van der Zwet's contribution sheds light on micro-foundations of the SNRP-immigration nexus.

The second article by Craig McAngus focuses on Plaid Cymru's struggle to reconcile its goal of Welsh revivalism with its more pragmatic concerns of economic vitality and immigrant integration. The party has received growing support since the 1960s when it matured from a loose coalition of nationalist organizations into a modern political party. Since 2006, the Welsh Assembly’s competencies have expanded into areas relevant to immigrant integration (e.g. education, housing). Plaid Cymru has been confronted with the possibility that migration from the rest of the United Kingdom and abroad will disrupt its plans to increase the societal prestige of the Welsh language through a series of planning laws. Immigration may not be the most salient issue in Wales, but McAngus demonstrates that an ethnic conception of identity rests uneasily aside official civic projections of the nation. Using interviews and documentary data, McAngus captures the evolving internal debate that is taking place within Plaid Cymru as the party considers its plans to confront the 'legitimation paradox' that diversity raises for sub-state nationalists.

Sanjay Jeram provides us with a window into the politics surrounding the transformation of the Basque Country into an immigrant-receiving territory. PNV-the largest SNRP in the Basque Country-has been at the helm of the autonomous Basque government for the lion's share of time since the transition to democracy, overseeing one of the strongest economies in Spain, which has made it an attractive destination for 
foreign migrants in recent years. Even though the xenophobic nationalist Sabino Arana founded the party, PNV has been a strong supporter of robust social rights for immigrants and vociferous critic of the Spanish's state treatment of 'irregular' migrants. Of course, there are clear nation-building objectives driving PNV to position itself as distinct from state-wide parties on immigration issues. Nevertheless, Jeram's analysis of interview transcripts and party manifestos elucidates a complex story in which party elites work with the nation's myths, symbols and narratives to define its immigration agenda rather than solely prioritizing instrumental goals. Jeram locates his argument firmly within the ethnosymbolist tradition commenced by Anthony Smith, and in doing so, cautions against assuming that SNRPs face the same incentives and constraints in the broad realm of immigration-policy making as do state-wide parties.

Verena Wisthaler's paper examines how institutionalized relations between autochthonous groups within a culturally distinct region can influence, in unexpected ways, the tenor and trajectory of SNRP positions on migration from non-traditional sources. South Tyrol is a province of Italy with a dominant German-speaking population and Italian- and Ladin-speaking minorities that maintain separate institutions through a system known as 'tolerance through law'. The institutionalization of boundaries between the three linguistic groups has propagated the phenomenon of 'thinking in terms of groups' among elites that shapes their perspectives on immigrant integration. Using longitudinal qualitative analysis of party manifestos, Wisthaler traces the immigration agendas of the SNRPs claiming to represent the German and Ladin minorities between 1990 and 2013. Wisthaler argues that the parties deliberately highlight immigration as a challenge to the strength of their respective cultures and languages, as well as the array of 
institutions that support the separate but equal coexistence of South Tyrol's autochthonous ethnic groups. In doing so, the article tells an intriguing story about the potential negative consequences of erecting consociational institutions within a sub-state region for the integration of newcomers. The perverse tendency to 'think in groups' has left little room for genuine political debate about the integration of migrants from the 'new' Europe and global South into South Tyrolean society.

Ilke Adam and Kris Deschouwer add a fresh case to the nationalism-immigration nexus in Flanders, focusing on Volksunie - the first Flemish SNRP — and its two successors (Spirit and New Flemish Alliance-NV-A) rather than the headline-grabbing radical right-wing VB. The article analyses the party manifestos of the three parties from the 1970s until the current period, providing us with a nuanced picture of how mainstream Flemish nationalism has evolved with respect to the 'legitimation paradox'. Taking cues from the literatures on political parties and immigrant integration, Adam and Deschouwer argue that Volksunie and its successor parties have generated immigration discourses that are expressive of their conceptions of the boundaries and content of the Flemish nation. Their findings call into question analytical frameworks that lump SNRPs and mainstream parties together; SNRPs face unique ideational constraints, argue the authors, and do not always adopt vote-maximising positions in the immigration ambit.

Núria Franco-Guillén's article examines SNRP immigration discourses from a unique political economy perspective. The 'selfishness of the affluent' thesis suggests that SNRPs in regions with relatively strong economies are more likely to adopt antiimmigrant positions, especially during an economic crisis because of the perception that 'insiders' and 'outsiders' are competing for scarce resources. Franco-Guillén explores 
this hypothesis with a compelling comparison: SNP in Scotland and Esquerra Republicana per Catalunya (ERC) in Catalonia are both left-leaning independenceseeking SNRPs, but Catalonia's advanced industrial economy makes it comparatively 'rich' in Spain while Scotland remains 'poor' relative to the United Kingdom. FrancoGuillén uncovers striking similarities between the discourses of the two parties across a number of policy dimensions relevant to immigration, such as migrant access to social welfare and multiculturalism, contradicting the theoretical expectation of divergence. The unforeseen conclusion, then, is that the immigration portfolios of both parties are shaped by the norms of civic nationalism that counterbalance material and populist impulses.

\section{Conclusion}

The contributions to this special edition of JEMS will, we trust, provoke further debate and research on the nexus between 'nations without states' and immigration. On one hand, immigrants may be portrayed as 'enemies', threatening the cultural and linguistic unity that undergirds SNRP claims to self-determination. On the other hand, new immigrants can be portrayed as 'friends' of sub-state nations, boosting regional economic vitality and integrating into the group's language and culture. By bringing together specialists of different cases and zeroing in on SNRPs - key political actors in a regionalized Europe - we present a complex and nuanced picture of the ways in which these parties are negotiating whether indeed immigrants are 'friends or foes' in the tugof-war between states and non-state nations.

Going forward, our intention is for this edition to inspire more work on topics that we as yet know little about. States in Europe (and North America) are in the process of 
reforming their programmes of immigrant integration with an eye to create a more 'muscular' concept of citizenship, an agenda that is sure to clash with regional integration programmes, especially in territories with strong national identities. Kymlicka (2011, 293) has suggested that multination states should promote citizenship agendas that make immigrants feel 'at home' in the country's various national cultures; the tendency for states to use citizenship as a means to assert its 'moral superiority [with immigrants]...is a predictable move within an old game of national rivalry'. More work should examine where and why citizenship agendas at the state and regional levels are conflicting, possible generating insights as to how devolved states can better foster multilevel cooperation to integrate in a manner that considers the best interests of migrants rather than turning them into pawns in nationalist conflicts.

Secondly, we need to amass more data and knowledge about public opinion towards immigration in sub-state nations. Public opinion studies about immigration at the state level are flourishing (Strabac, Aalberg, and Valenta 2014; Wilkes and CorrigallBrown 2011), but concerns about cultural insecurity and self-determination are good reasons to consider sub-state nations separately from broader opinion. As of yet, the available data makes it difficult to elucidate broad comparative statements about public opinion towards immigrants in sub-state nations (Jeram 2014). Collecting comparable data across nationalist regions in liberal democracies will go a long way toward better understanding how the public thinks about immigration and diversity, allowing scholars of SNRPs and regional politics to consider if elites are making decisions that are insulated from broader opinions. 
Finally, research on the effects of regional citizenship and integration policy in sub-state nations from governance and public policy perspectives are needed. We still know little about the tangible effects differentiated integration regimes have on immigrants in terms of identity, linguistic skills, labour market participation, and other standard integration measures. Such work will be illuminating since SNRPs make the case that the ability to tailor integration and citizenship policies to the needs of their national territories and communities inevitably leads to better outcomes for both migrants and their hosts.

Ultimately, we believe that the papers in this special issue of JEMS contribute to a research programme that is vitally important and timely. Immigration-related issues remain at the top of the policy and social agendas across the Western world and sub-state nationalist mobilizations have not waned, as many modernization, globalization and Marxist theorists predicted; the upcoming referendum in Scotland and planned referendum in Catalonia are indicative of continued feelings of national solidarity below the state. The crossing of paths between sub-state nationalists and immigrants has brought states, regional governments, political parties, and immigrants into complex relationships that will continue to be debated and politicized for decades to come.

\section{References}

Adam, Ilke. 2013. "Immigrant Integration Policies of the Belgian Regions: Sub-State Nationalism and Policy Divergence After Devolution." Regional \& Federal Studies 23 (5): 547-569.

Akkerman, Tjitske. 2012. "Comparing Radical Right Parties in Government: Immigration and Integration Policies in Nine Countries (1996-2010)." West European Politics 35 (3): 511-529.

Banting, Keith and Stuart Soroka. 2012. "Minority Nationalism and Immigrant Integration in Canada." Nations \& Nationalism 18 (1): 156-176. 
Bale, Tim, Christoffer Green-Pedersen, Andre Krouwel, Kurt Richard Luther, and Nick Sitter. 2010. "If You Can't Beat Them, Join Them? Explaining Social Democratic Responses to the Challenge from the Populist Radical Right in Western Europe." Political Studies 58 (3): 410-426.

Barker, Fiona C. 2010. "Learning to be a Majority: Negotiating Immigration, Integration, and National Membership in Quebec." Political Science 62 (1): 11-36.

Blad, Cory and Philippe Couton. 2009. "The Rise of an Intercultural Nation: Immigration, Diversity and Nationhood in Quebec." Journal of Ethnic and Migration Studies 35 (4): 645-667.

Bromley, Catherine, John Curtice and Lisa Given. 2007. Attitudes to Discrimination in Scotland: 2006. Edinburgh: Scottish Government Social Research.

Brubaker, Rogers. 1992. Citizenship and Nationhood in France and Germany. Cambridge: Harvard University Press.

Carens, Joseph H. 1995. "Immigration, Political Community, and the Transformation of Identity: Quebec's Immigration Politics in Critical Perspective.” In Is Quebec Nationalism Just? Perspectives from Anglophone Canada, edited by Joseph H.

Carens, 20-81. Montreal: McGill University Press.

Conversi, Daniele. 1997. The Basques, the Catalans, and Spain: Alternative Routes to Nationalist Mobilisation. London: Hurst.

Cook, Ramsay. 1975. French-Canadian Nationalism: An Anthology. Toronto: Macmillan of Canada.

Douglass, William A. 2002. "Sabino's Sin: Racism and the Founding of Basque Nationalism." In Ethnonationalism in the Contemporary World, edited by Daniele Conversi, 95-112. New York: Routledge.

Elias, Anwen and Filippo Tronconi. 2011. "From Protest to Power: Autonomist Parties in Government." Party Politics 17 (4): 505-524.

Entzinger, Han. 2006. "Changing the Rules when the Game is on: From Multiculturalism to Assimilation in the Netherlands and Beyond." In Migration, Citizenship, Ethnos: Incorporation Regimes in Germany, Western Europe and North America, edited by Michal Bodemann and Gokce Yurdukal, 121-144. New York: Palgrave MacMillan.

Escandell, Xavier and Alin Ceobanu. 2010. "Nationalisms and Anti-Immigrant Sentiment in Spain.” South European Society \& Politics 15 (2): 157-157-179.

Franck, Thomas M. 1997. "Tribe, Nation, World: Self-Identification in the Evolving International System." Ethics and International Affairs 11: 150-170.

Goodman, Sara Wallace. 2010. "Integration Requirements for Integration's Sake? Identifying, Categorising and Comparing Civic Integration Policies.” Journal of Ethnic and Migration Studies 36 (5): 753-772.

Greer, Scott and Margitta Mätzke. 2009. "Introduction: Devolution and Citizenship Rights." In Devolution and Social Citizenship in the UK, edited by Scott Greer and Margitta Mätzke, 1-19. Bristol: Polity Press.

Hechter, Michael. 1975. Internal Colonialism: The Celtic Fringe in British National Development. Berkeley: University of California Press.

Hepburn, Eve. 2008. "The Neglected Nation: The CSU and the Territorial Cleavage in Bavarian Party Politics." German Politics 17 (2): 184-202.

Hepburn, Eve. 2009. "Introduction: Re-Conceptualizing Sub-State Mobilization." Regional and Federal Studies 19 (4): 477-499. 
Hepburn, Eve. 2010. Using Europe: Territorial Party Strategies in a Multi-Level System. Manchester: Manchester University Press.

Hepburn, Eve. 2011. "Citizens of the Region: Party Conceptions of Regional Citizenship and Immigrant Integration.” European Journal of Political Research 50: 504-529.

Hepburn, Eve and Ricard Zapata-Barerro, eds. 2014. The Politics of Immigration of Immigration in Multi-Level States: Governance and Political Parties. New York: Palgrave Macmillan.

Hepburn, Eve. 2014. "Multilevel Party Politics of Immigration: Territorial Rescaling and Party Competition." In The Politics of Immigration of Immigration in Multi-Level States: Governance and Political Parties, edited by Eve Hepburn and Ricard Zapata Barrero, 66-95. New York: Palgrave Macmillan.

Hobsbawm, Eric J. 1990. Nations and Nationalism since 1780: Programme, Myth, Reality. New York: Cambridge University Press.

Hollinger, David A. 1995. Post-ethnic America: Beyond Multiculturalism. New York: Basic Books.

Ignatieff, Michael. 1993. Blood and Belonging: Journeys into the New Nationalism. Toronto: Viking.

Jacobs, Dirk. 2004. "Alive and Kicking: Multiculturalism in Flanders." International Journal on Multicultural Societies 6 (2): 280-289.

Jeram, Sanjay. 2013. "Immigrants and the Basque Nation: Diversity as a New Marker of Identity." Ethnic \& Racial Studies 36 (11): 1770-1788.

Jeram, Sanjay. 2014. "Sub-State Nationalism and Immigration in Spain: Diversity and Identity in Catalonia and the Basque Country." Ethnopolitics 13 (3): 225-244.

Jeram, Sanjay and Ilke Adam. 2014. "Diversity and Nationalism in the Basque Country and Flanders: Understanding Immigrants as Fellow Minorities." National Identities, doi: 10.1080/14608944.2014.951611

Johnston, Simon. 2013. "Michael Moore: Immigration a 'Nightmare' if Scotland Votes for Independence." The Telegraph, July 13. http://www.telegraph.co.uk/news/uknews/scotland/10214943/Michael-MooreImmigration-a-nightmare-if-Scotland-votes-for-independence.html

Joppke, Christian. 2008. "Immigration and the Identity of Citizenship." Citizenship Studies 12 (6): 533-546.

Joppke, Christian. 2010. Citizenship and Immigration. Cambridge: Polity.

Juteau, Danielle. 2003. "The Citizen Makes an Entrée: Redefining the National Community in Quebec." Citizenship Studies 6 (4): 441-458.

Keating, Michael. 2004. "European Integration and the Nationalities Question." Politics and Society 32 (3): 367-388.

Keating, Michael. 2008. "Thirty Years of Territorial Politics.” West European Politics 31 (1): 60-81.

Kohn, Hans. 1945. The Idea of Nationalism. New York: Macmillan.

Koning, Edward A. 2011. "Ethnic and Civic Dealings with Newcomers: Naturalization Policies and Practices in Twenty-Six Immigration Countries." Ethnic \& Racial Studies 34 (11): 1974-1994.

Kymlicka, Will. 2001. "Immigrant Integration and Minority Nationalism.” In Minority Nationalism and the Changing International Order, edited by John McGarry and Michael Keating, 61-83. Oxford: Oxford University Press. 
Kymlicka, Will. 2007. Multicultural Odysseys: Navigating the New International Politics of Diversity. Oxford: Oxford University Press.

Kymlicka, Will. 2011. "Multicultural Citizenship within Multination States." Ethnicities 11 (3): 281-302.

Laxer, Emily, Rachel D. Carson, and Anna C. Korteweg. 2014. “Articulating Minority Nationhood: Cultural and Political Dimensions in Quebec's Reasonable Accommodation Debate." Nations \& Nationalism 20 (1): 133-153.

Lecours, André. 2012. "Sub-State Nationalism in the Western World: Explaining Continued Appeal." Ethnopolitics 11 (3): 268-286.

Loobuyck, Patrick and Dirk Jacobs. 2009. "Nationalism, Multiculturalism and Integration Policy in Belgium and Flanders." Canadian Issues 3 (1): 29-40.

Money, Jeannette. 1999. Fences and Neighbours: The Political Geography of Immigration Control. Ithaca: Cornell University Press.

Mouritsen, Pen and Tore Vincents Olsen. 2013. "Denmark between Liberalism and Nationalism." Ethnic and Racial Studies 36 (4): 691-710.

Mycock, Andrew. 2012. "SNP, Identity and Citizenship: Re-Imagining State and Nation." National Identities 14 (1): 53-69.

Nieguth, Tim. 1999. "Beyond Dichotomy: Concepts of the Nation and the Distribution of Membership." Nations and Nationalism 5 (2): 155-173.

Nieguth, Tim and Aurélie Lacassagne. 2009. "Contesting the Nation: Reasonable Accommodation in Rural Quebec.” Canadian Political Science Review 3 (1): 1-16.

Norman, Wayne. 2006. Negotiating Nationalism: Nation-Building, Federalism, and Secession in the Multinational State. New York: Oxford University Press.

Reicher, Steven, Nicholas Hopkins, and Kate Harrison. 2009. "Identity Matters: On the Importance of Scottish Identity for Scottish Society." In National Identity, Nationalism and Constitutional Change, edited by Frank Bechhofer and David McCrone, 17-40. Basingstoke: Palgrave Macmillan.

Schmidtke, Oliver and Andrej Zaslove. 2013. "Why Regions Matter in Immigrant Integration Policies: North Rhine-Westphalia and Emilia-Romagna in Comparative Perspectice." Journal of Ethnic and Migration Studies, DOI:

10.1080/1369183X.2013.867232

Strabac, Zan, Toril Aalberg, and Marko Valenta. 2014. "Attitudes Towards Muslim Immigrants: Evidence from Survey Experiments Across Four Countries.” Journal of Ethnic \& Migration Studies 40 (1): 100-118.

Soysal, Yasemin N. 1994. Limits of Citizenship: Migrants and Postnational Membership in Europe. Chicago: University of Chicago.

Tamir, Y. 1993. Liberal Nationalism, Princeton, Princeton University Press.

Triadafilopoulos, Triadafilos and Andrej Zaslove. 2006. "Influencing Migration Policy from Inside: Political Parties." In Dialogues on Migration Policy, edited by Marco Giugni and Florence Passy, 171-192. Lanham: Lexington Books.

Triadafilopoulos, Triadafilos. 2011. "Illiberal Means to Liberal Ends? Understanding Recent Immigrant Integration Policies in Europe." Journal of Ethnic and Migration Studies 37 (6): 861-880.

Turgeon, Luc and Antoine Bilodeau. 2014. "Minority Nations and Attitudes Towards Immigration: The Case of Quebec.” Nations and Nationalism 20 (2): 317-336. 
Urla, Jacqueline. 2012. Reclaiming Basque: Language, Nation, and Cultural Activism. Reno, NV: University of Nevada Press.

van der Zwet, A. 2012. "A Comparison of Civic and Ethnocultural National Identities in the Scottish National Party and Frisian National Party and their Impact on Attitudes towards European Integration, Immigration and Multiculturalism." PhD diss., University of Strathclyde.

Wilkes, Rima and Catherine Corrigall-Brown. 2011. "Explaining Time Trends in Public Opinion: Attitudes Towards Immigration and Immigrants." International Journal of Comparative Sociology 52 (1): 79-99.

Yack, Bernard. 1999. "The Myth of the Civic Nation." In Theorizing Nationalism, edited by Ronald Beiner, 103-118. Albany, NY: State University of New York Press.

Zabalo, Julen. 2008. "Basque Nationalism's Changing Discourse on the Nation." Social Identities 14 (6): 795-811.

Zapato-Barrero, Ricard and Fiona Barker. 2014. "Multilevel Governance of Immigration in Multinational States." In The Politics of Immigration of Immigration in MultiLevel States: Governance and Political Parties, edited by Eve Hepburn and Ricard Zapata Barrero, 37-66. New York: Palgrave Macmillan.

Zapata-Barrero, Ricard. 2012. "Spain." In Immigration Integration in Federal Countries, edited by Christian Joppke and F. Leslie Seidle, 135-160. Montreal: McGill-Queens University Press. 